\title{
Wpływ ekstraktów z pokrzywy zwyczajnej (Urtica dioica L.) na aktywność katalazy w monocytach/makrofagach THP1*
}

\section{The influence of stinging nettle (Urtica dioica L.) extracts on the activity of catalase in THP1 monocytes/macrophages}

\author{
Jolanta Wolska', Katarzyna Janda', Sylwia Szkyrpan², Izabela Gutowska' \\ 1 Zakład Biochemii i Żywienia Człowieka Pomorskiego Uniwersytetu Medycznego w Szczecinie \\ ul. Broniewskiego 24, 71-460 Szczecin \\ Kierownik: prof. dr hab. n. med. Ewa Stachowska \\ ${ }^{2}$ Wydział Nauk o Zdrowiu Pomorskiego Uniwersytetu Medycznego w Szczecinie \\ ul. Żołnierska 48, 71-210 Szczecin \\ Dziekan: prof. dr hab. n. zdr. Beata Karakiewicz
}

\section{SUMMARY}

Introduction: Stinging nettle (Urtica dioica L.) is one of the most valuable plants used in phytotherapy. The herbal raw material is a herb (Urticae herba), leaves (Urticae folium), roots (Urticae radix) and seeds (Urticae semina). This plant is a good source of vitamins, minerals, fibre, protein and biologically active compounds with antioxidant properties. The literature provides limited information about the chemical composition and properties of the seed heads. No papers are available on the effect of extracts of this plant on catalase activity in human cells.

The aim of this study was to investigate the impact of stinging nettle (Urtica dioica L.) extracts on the antioxidant activity of catalase in THP1 macrophages.
Material and methods: Two types of extracts: water and alcohol, at two different concentrations, were used in experiments. Nettle was collected in September and October in 2012 in the area of Szczecin. The collected plant material was frozen and lyophilized. After those procedures water and alcohol extracts of nettle were prepared and then added to THP1 cells.

Results and conclusions: The antioxidant activity of catalase was established with the spectrophotometric method. The study showed that both extracts (water and alcohol) significantly increased the antioxidant activity of catalase in THP1 cells. The increase in catalase was directly proportional to the concentration of the added alcohol extract.

Key words: seed heads, human cells, catalase.

\section{STRESZCZENIE}

Wstęp: Pokrzywa zwyczajna (Urtica dioica L.) jest jedną z najcenniejszych roślin stosowanych w fitoterapii. Surowcem zielarskim są: ziele (Urticae herba), liście (Urticae folium), korzenie (Urticae radix) oraz nasiona (Urticae semina). Roślina ta jest cennym źródłem witamin, minerałów, błonnika, białka oraz związków biologicznie czynnych o właściwościach przeciwutleniających. W dostępnej literaturze nieliczne są informacje na temat składu chemicznego i właściwości owocostanów. Nie znaleziono prac dotyczących wpływu ekstraktów tej rośliny na aktywność katalazy w komórkach ludzkich.

Celem pracy było zbadanie wpływu ekstraktów alkoholowych i wodnych z owocostanów pokrzywy zwyczajnej (Urtica dioica L.) na właściwości przeciwutleniające katalazy w komórkach THP1 (ludzka linia monocytarna nowotworowa - białaczka).

Materiał i metody: Owocostany zebrane na przełomie września i października 2012 r. zamrożono i zliofilizowano. Z wysuszonego materiału roślinnego przygotowano ekstrakty (wodny i alkoholowy), które dodawano do hodowli komórkowych w różnym stężeniu. Do oznaczenia aktywności katalazy w komórkach wykorzystano metodę spektrofotometryczną.

Wyniki i wnioski: Wykazano, że oba ekstrakty (wodny i alkoholowy) z owocostanów pokrzywy zwyczajnej powodują zwiększenie aktywności przeciwutleniającej katalazy w komórkach THP1. Wzrost aktywności katalazy w komórkach był wprost proporcjonalny do stężenia dodanego ekstraktu alkoholowego.

Słowa kluczowe: owocostany pokrzywy, komórki ludzkie, katalaza.

\section{WSTĘP}

Pokrzywa zwyczajna (Urtica dioica L.) to wieloletnia roślina uważana za pospolity chwast $[1,2]$. Zasiedla okolice domostw, ogrody, polany, pastwiska, zarośla i lasy liściaste [2, 3]. Kwitnie i owocuje od czerwca do października [4]. W ziołolecznictwie

wykorzystywane są wszystkie części tej rośliny: ziele (Urticae herba), liście (Urticae folium), korzenie (Urticae radix), a także choć rzadko - nasiona (Urticae semina) [2, 3, 5, 6]. Urtica dioica L to cenne źródło minerałów (K, Fe, Mn, Mg, P, S, Si, Na, Ca), witamin (A, D, E, K, C, B2), błonnika, białka, flawonoidów, garbników, chlorofilu, karotenoidów oraz kwasów organicznych

\footnotetext{
* Artykuł powstał na podstawie pracy magisterskiej Sylwii Szkyrpan pt. „Wpływ ekstraktów pokrzywy na aktywność katalazy w makrofagach THP1”, której oryginał
} obejmuje 69 stron. 
(glicerolowego, glikolowego i mrówkowego) [4, 7]. Według Nowaka [8] zawartość kwasu askorbinowego w zielu sięga nawet $600 \mathrm{mg} \%$. Spożywanie przetworów, potraw i suplementów diety zawierających pokrzywę może pomóc w uzupełnianiu niedoborów tych związków w organizmie człowieka i zwierząt, nie wyłączając kobiet w ciąży $[1,3,4,9,10]$. Surowcem mniej popularnym, choć bardzo wartościowym, są nasiona pokrzywy. Zawierają ok. 30\% tłuszczu, będącego źródłem cennych nienasyconych kwasów tłuszczowych, z przewagą kwasu linolowego i oleinowego. Olej z nasion pokrzywy zawiera również izomery tokoferolu $(\alpha, \delta$ oraz $\gamma$ ) oraz minerały (Ca, $\mathrm{Mg}$, Fe i Zn) [11].

Pokrzywa to jedna z wartościowszych roślin wykorzystywana w fitoterapii do łagodzenia stanów zapalnych i alergii, redukcji bólu, obniżania ciśnienia tętniczego, stymulowania krążenia krwi, odtruwania organizmu, obniżania glikemii, pobudzania układu odpornościowego (aktywność przeciwdrobnoustrojowa), obniżania poziomu cholesterolu, chlorku sodu i mocznika, wzmagania diurezy, wspomagania trawienia (ułatwia przemianę materii) oraz gojenia się ran, stymulowania procesu odbudowy tkanek, przywracania równowagi hormonalnej oraz powstrzymywania procesów powodujących wypadanie włosów. Surowiec ten działa wzmacniająco w terapii przeciwnowotworowej, przeciwobrzękowo, przeciwkrwotocznie, przeciwmiażdżycowo, przeciwłupieżowo, przeciwłojotokowo i przeciwtrądzikowo, pomaga w oczyszczaniu zatok obocznych nosa, chroni przed suchym kaszlem oraz ma właściwości przeciwutleniające $[1,3,5,7,12]$.

W ostatnich latach dużą uwagę przywiązuje się do przeciwutleniaczy roślinnych. Są one szczególnie cenne ze względu na większą stabilność niż syntetyczne, a poza tym mają istotne znaczenie dla zdrowia, działając przeciwnowotworowo, obniżając ryzyko zachorowania na choroby serca oraz hamując tempo niekorzystnych zmian związanych ze starzeniem się organizmu [11, 13, 14]. Krauze-Baranowska [12] wykazała, że wodny ekstrakt z części nadziemnej pokrzywy zwyczajnej ma silne właściwości przeciwutleniające, wynikające z dużej zawartości związków polifenolowych. Badania Pieszak i Mikołajczak [3] udowodniły występowanie przeciwutleniaczy - flawonoidów w liściach, natomiast wg Chrubasik i wsp. [15] - w zielu Urtica dioica $\mathrm{L}$.

W organizmie człowieka zachodzi oddziaływanie między antyoksydantami egzogennymi a niskocząsteczkowymi antyoksydantami endogennymi i enzymami. Do enzymatycznej obrony antyoksydacyjnej należą: katalaza, peroksydazy ponadtlenkowe, dysmutazy ponadtlenkowe, reduktaza glutationowa i S-transferazy glutationowe, które chronią ustrój przed reaktywnymi formami tlenu [16]. Zbyt duża ilość tych form tlenu sprzyja wystąpieniu stresu oksydacyjnego objawiającego się uszkodzeniem lipidów, białek i kwasów nukleinowych w organizmie człowieka. Katalaza w organizmie człowieka odpowiedzialna jest za rozkładanie w komórkach nadtlenku wodoru [17]. W związku z powyższym ważne jest prowadzenie badań nad związkami wspomagającymi pracę enzymów przeciwutleniających. W dostępnej literaturze znaleziono dane na temat składu chemicznego i właściwości ziela, liści i kłączy pokrzywy zwyczajnej, natomiast brak jest informacji dotyczących owocostanów. Nie znaleziono także badań poświęconych wpływowi ekstraktów tej rośliny na aktywność katalazy w komórkach ludzkich.

Celem pracy było zbadanie wpływu ekstraktów alkoholowych i wodnych z owocostanów pokrzywy zwyczajnej (Urtica dioica L.) na właściwości przeciwutleniające katalazy w komórkach THP1 (ludzka linia monocytarna nowotworowa - białaczka).

\section{MATERIA I METODY}

\section{Przygotowanie materiału roślinnego}

Surowcem roślinnym były owocostany pokrzywy zwyczajnej (Urtica dioica L.), zebrane na terenach zielonych Szczecina we wrześniu i październiku 2012 r. Po oczyszczeniu zostały zamrożone $\mathrm{w}$ temp. $-80^{\circ} \mathrm{C}$, a następnie poddane liofilizacji $\mathrm{w}$ aparacie Alpha 1-2 LD plus (ciśnienie 0,735 $\mathrm{mmHg}$, temp. $-20^{\circ} \mathrm{C}$ ). Wysuszony i zhomogenizowany przez utarcie w moździerzu materiał wykorzystano do przygotowania ekstraktów (alkoholowego i wodnego).

\section{Przygotowanie ekstraktów}

1. Ekstrakt alkoholowy. $5 \mathrm{~g}$ suszu przeniesiono do kolby o pojemności $500 \mathrm{~mL}$ i dodano $300 \mathrm{~mL} \mathrm{70 \%} \mathrm{etanolu.} \mathrm{Mieszaninę}$ utrzymywano 3 godz. w temp. wrzenia $\left(80^{\circ} \mathrm{C}\right)$ w łaźni wodnej pod chłodnicą zwrotną, następnie schłodzono do temperatury pokojowej i przefiltrowano. Przesącz alkoholowy poddano 4-krotnej ekstrakcji eterem naftowym. Zebrane warstwy alkoholowe połączono i ekstrahowano ostatni, piąty raz eterem naftowym. Alkohol odparowano na wyparce rotacyjnej pod zmniejszonym ciśnieniem.

2. Ekstrakt wodny. Do kolby o pojemności $300 \mathrm{~mL}$ odważono $1 \mathrm{~g}$ suszu i wprowadzono $100 \mathrm{~cm}^{3}$ destylowanej wody o temp. $90^{\circ} \mathrm{C}$. Kolbę zamkniętą korkiem wytrząsano przez 10 min w temperaturze pokojowej, po czym przefiltrowano. W celu odparowania rozpuszczalnika przesącz poddano destylacji pod zmniejszonym ciśnieniem w wyparce rotacyjnej.

Suche ekstrakty przechowywano w temp. $-20^{\circ} \mathrm{C}$.

\section{Hodowla komórek THP1}

W doświadczeniu wykorzystano komórki THP1 (ATCC, Rockville, USA), które w ilości $3 \times 10^{6}$ posiano na 6-dołkowych płytkach. W celu przekształcenia monocytów w makrofagi do komórek dodawano po 100 nM PMA (phorbol 12-myristate 13 -acetate) i inkubowano przez 24 godz. $\left(37^{\circ} \mathrm{C}, 5 \% \mathrm{CO}_{2}\right)$. Po tym czasie komórki przemywano 3-krotnie ciepłym PBS i dodawano po $2 \mu \mathrm{L}$ ekstraktu wodnego lub alkoholowego z owocostanów pokrzywy zwyczajnej. Ostateczne stężenie w dołku ekstraktu wodnego wyniosło PW1 $=15 \mu \mathrm{g} / \mathrm{mL}, \mathrm{PW} 2=7,5 \mu \mathrm{g} / \mathrm{mL}$, natomiast ekstraktu etanolowego PA1 $=10 \mu \mathrm{g} / \mathrm{mL}, \mathrm{PA} 2=5 \mu \mathrm{g} / \mathrm{mL}$. Kontrolę pozytywną (K+) stanowiły komórki hodowane $\mathrm{z}$ dodatkiem $2 \mu \mathrm{L}$ DMSO (dimetylosulfotlenek), kontrolę negatywną (K-) bez dodatku tego związku. Po 48 godz. inkubacji $\left(37^{\circ} \mathrm{C}, 5 \% \mathrm{CO}_{2}\right)$ komórki zdrapywano z płytki i odwirowywano $\left(4^{\circ} \mathrm{C}, 10 \mathrm{~min}\right.$, 
$1800 \mathrm{obr} . / \mathrm{min})$. Supernatant odrzucano, a otrzymaną peletkę komórek zamrażano w temp. $-80^{\circ} \mathrm{C}$. W każdej próbce oznaczano zawartość białka metodą Bradford [18].

\section{Oznaczenie aktywności katalazy metodą spektrofotometryczną}

Aktywność katalazy w komórkach oznaczano na spektrofotometrze UV-Vis Agilent 5453 według metody opracowanej przez Aebi i wsp. [19]. W kwarcowej kuwecie mieszano $50 \mu \mathrm{L}$ badanej próbki, $950 \mu \mathrm{L}$ buforu fosforanowego (0,067 M bufor fosforanowy o $\mathrm{pH}=7,00$ ) i $500 \mu \mathrm{L} 30 \mathrm{mM} \mathrm{H}_{2} \mathrm{O}_{2} \mathrm{w}$ buforze. Po delikatnym wymieszaniu wykonywano analizy spektrofotometryczne.

Zmiana stężenia nadtlenku wodoru w wyniku działania przeciwutleniającego katalazy mierzona jest jak stała szybkości reakcji pierwszorzędowej. Obliczenia wykonano na podstawie równania:

$$
k=\frac{2,3}{t_{2}-t_{1}} \cdot \log \left(\frac{A_{1}}{A_{2}}\right)
$$

gdzie:

$A_{1}$ - absorbancja dla $\lambda=240 \mathrm{~nm}$ w czasie $t_{1}$

$A_{2}$ - absorbancja dla $\lambda=240 \mathrm{~nm}$ w czasie $t_{2}$

$t_{1}$ - czas rozpoczęcia pomiaru próbki [s]

$t_{2}$ - czas, po którym absorbancja badanej próbki dla $\lambda=240 \mathrm{~nm}$ zmniejszyła się o 0,05 [s]

$k$-stała szybkości reakcji pierwszego rzędu $\left[\mathrm{s}^{-1}\right][20]$.

Ze względu na nietypową kinetykę enzymu katalazy, w celu wyznaczenia jej aktywności przeciwutleniającej zamiast używania jednostek katalazy (U) zastosowano stałą szybkości reakcji pierwszorzędowej przeliczoną na gram białka. Aktywność katalazy wyrażoną jako k/g białka obliczono wg wzoru [20]:

$$
k / g \text { białka }=\frac{\frac{69}{\Delta t} \cdot \log \left(\frac{A_{1}}{A_{2}}\right)}{\text { białko }\left[\frac{g}{m L}\right]}
$$

Otrzymane wyniki poddano analizie statystycznej z wykorzystaniem programu Statistica 10.1 (StatSoft, Polska). W celu sprawdzenia rozkładu wyników uzyskanych dla różnych parametrów wykonano test Shapiro-Wilka. Ponieważ większość rozkładów odbiegała od rozkładu normalnego, do dalszej analizy statystycznej użyto testów nieparametrycznych. W celu określenia różnic istotnych statystycznie dla próbek zależnych w pierwszej kolejności wykonano analizę wariancji testem ANOVA Friedmana, a następnie zastosowano test kolejności par Wilcoxona. Za poziom istotności przyjęto $\mathrm{p} \leq 0,05$.

\section{OMÓWIENIE WYNIKÓW I DYSKUSJA}

Aktywność katalazy oznaczona w kontroli negatywnej (K-) i kontroli pozytywnej (K+; komórki hodowane z dodatkiem
DMSO) była zbliżona i wynosiła odpowiednio: 10,54 $\pm 0,65 \mathrm{k} / \mathrm{g}$ białka dla K- oraz 9,92 $\pm 0,36$ k/g białka dla K+. Nie wykazano różnic istotnych statystycznie między tymi wartościami, co oznacza, iż DMSO, stosowany jako nośnik ekstraktów z owocostanów pokrzywy do komórek THP1, nie ma istotnego wpływu na aktywność przeciwutleniającą katalazy. Można zatem uznać, iż DMSO jest dobrym nośnikiem do wprowadzania ekstraktów roślinnych do komórek w prowadzonych hodowlach [21].

Na rycinie 1 przedstawiono aktywność przeciwutleniającą katalazy w komórkach THP1 po hodowli z dodatkiem alkoholowego ekstraktu z owocostanów pokrzywy zwyczajnej (Urtica dioica L.) o różnym stężeniu.

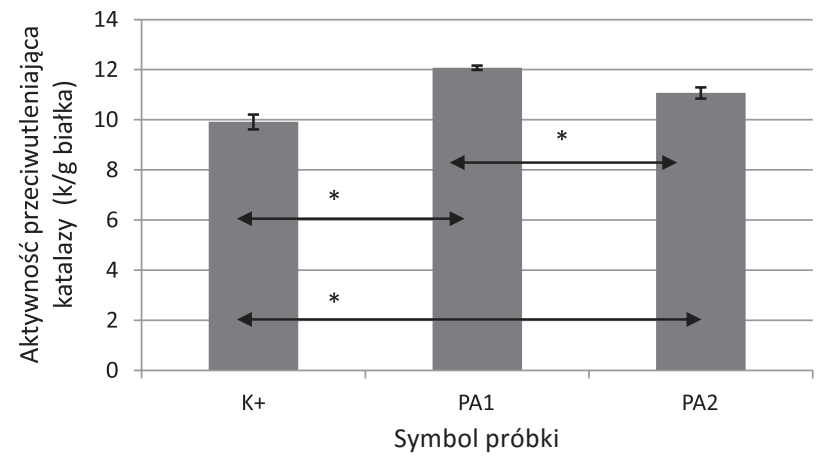

*różnice statystycznie istotne przy $p \leq 0.05$

RYCINA 1. Aktywność przeciwutleniająca katalazy w komórkach THP1 po hodowli z dodatkiem etanolowego ekstraktu (PA1, PA2) z owocostanów pokrzywy zwyczajnej (Urtica dioica L.)

Wykazano, że po dodaniu do medium ekstraktu alkoholowego z owocostanów pokrzywy zwyczajnej aktywność katalazy komórek THP1 zwiększyła się. W przypadku wyższego stężenia ekstraktu (10 $\mu \mathrm{g} / \mathrm{mL})$ w próbie PA1 stwierdzono wzrost aktywności katalazy o 21,8\% (2,16 k/g białka). W próbie PA2 ekstrakt alkoholowy o stężeniu $5 \mu \mathrm{g} / \mathrm{mL}$ spowodował wzrost aktywności o 11,6\% (1,15 k/g białka). Różnice pomiędzy kontrolą (K+) a wartościami dla PA1 i PA2 były statystycznie istotne $(\mathrm{p}<0,5)$.

Okazało się, że wzrost aktywności katalazy w komórkach był wprost proporcjonalny do stężenia dodanego ekstraktu alkoholowego. Przy dwukrotnym zwiększaniu stężenia ekstraktu wprowadzanego do medium hodowlanego dwukrotnemu zwiększeniu uległa wartość aktywności przeciwutleniającej katalazy w komórkach. Różnica ta była statystycznie istotna $(\mathrm{p}<0,5)$.

Na rycinie 2 przedstawiono aktywność przeciwutleniającą katalazy w komórkach THP1 po hodowli z dodatkiem wodnego ekstraktu z owocostanów pokrzywy zwyczajnej (Urtica dioica L.) o różnym stężeniu.

Dodatek ekstraktu wodnego z owocostanów pokrzywy do hodowli komórek THP1 również wywołał zmiany w aktywności katalazy. Znaczący wzrost aktywności tego enzymu spowodowała obecność w medium hodowlanym ekstraktu wodnego o stężeniu 15 g/mL (PW1). Aktywność katalazy była wyższa o 90\% (8,97 k/g białka) w porównaniu do kontroli 


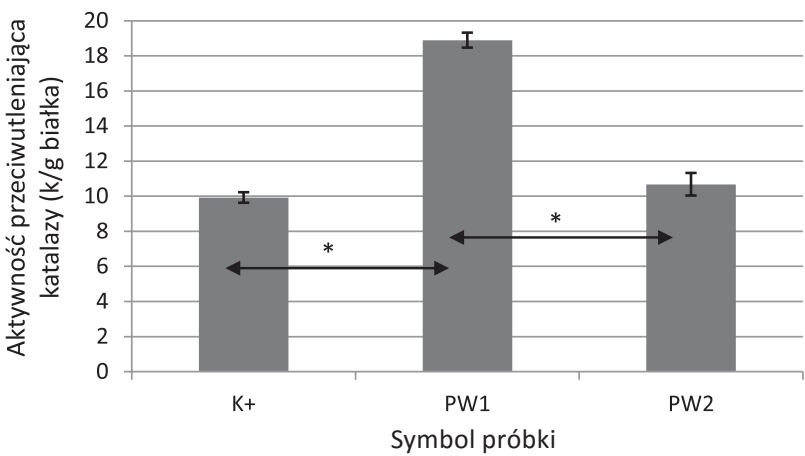

*różnice statystycznie istotne przy $p \leq 0.05$

RYCINA 2. Aktywność przeciwutleniająca katalazy w komórkach THP1 po hodowli z dodatkiem wodnego ekstraktu (PW1, PW2) z owocostanów pokrzywy zwyczajnej (Urtica dioica L.)

$(\mathrm{K}+)$. Różnica ta była statystycznie istotna $(\mathrm{p}<0,5)$. Obecność w medium hodowlanym wodnego ekstraktu PW2 o stężeniu o połowę mniejszym $(7,5 \mu \mathrm{g} / \mathrm{mL})$ nie wpłynęła istotnie na wzrost aktywność katalazy. Nie zaobserwowano, aby wyższe stężenie ekstraktu powodowało proporcjonalne zwiększenie aktywności katalazy.

Najwyższą aktywność katalazy stwierdzono w hodowlach z dodatkiem ekstraktu wodnego o najwyższym stężeniu (PW1, $15 \mu \mathrm{g} / \mathrm{mL}$ ). Różnica pomiędzy tą wartością a pozostałymi była statystycznie istotna $(\mathrm{p}<0,5)$.

Udowodniono, że ekstrakty wodne i alkoholowe z owocostanów pokrzywy zwyczajnej mają znaczący wpływ na aktywność przeciwutleniającą katalazy w komórkach THP1. Wykazano, że stężenie ekstraktu alkoholowego wpływało wprost proporcjonalnie na wzrost aktywności katalazy. Przeprowadzone badania wskazują, że ekstrakty z owocostanów Urtica dioica L. wzmagają pracę komórkowego systemu antyoksydacyjnego w makrofagach THP1 i dzięki temu mają korzystny wpływ na obronę organizmu przed wolnymi rodnikami. Wzrost aktywności katalazy skutkuje w organizmie wzmożoną pracą mechanizmu enzymatycznego (wchodzącego w skład bariery antyoksydacyjnej), który bierze udział w usuwaniu nadmiaru wolnych rodników, nadzorując przy tym procesy redukcji i utleniania w komórce. Mechanizm wzmożonej aktywności katalazy przyczynia się do zwiększenia obrony organizmu przed stresem oksydacyjnym oraz do powstania homeostazy procesów redukcji i utleniania w komórce. Ponadto badania te pozwoliły zweryfikować wpływ DMSO, stosowanego jako nośnik ekstraktów do komórek THP1, na aktywność przeciwutleniającą katalazy. Okazało się, iż związek ten nie zmienia aktywności katalazy obecnej w komórkach THP1, co czyni go dobrym, neutralnym nośnikiem ekstraktów.

Brak jest w dostępnej literaturze doniesień dotyczących wpływu ekstraktów owocostanów pokrzywy zwyczajnej na aktywność przeciwutleniającą katalazy w komórkach typu THP1, dlatego trudno jest podjąć dyskusję na temat uzyskanych wyników. W celu głębszego zweryfikowania badanych zależności należałoby kontynuować prowadzone badania, poszerzając je o nowe parametry.

\section{WNIOSKI}

1. Ekstrakty wodne i alkoholowe z owocostanów pokrzywy zwyczajnej wpływają na podniesienie potencjału antyoksydacyjnego komórek ludzkiej linii monocytarnej nowotworowej (białaczki).

2. Przeprowadzone badania wstępne wskazują na potrzebę dalszych doświadczeń, celem ustalenia optymalnego stężenia wykorzystanych ekstraktów roślinnych.

\section{PIŚMIENNICTWO}

1. Grau J., Jung R., Münker B.: Leksykon przyrodniczy. Zioła i owoce leśne. Świat Książki, Warszawa 1996.

2. Nartowska J.: Pokrzywa zwyczajna. Panacea. 2007, 3 (20), 6-9.

3. Pieszak M., Mikołajczak P.t.: Właściwości lecznicze pokrzywy zwyczajnej (Urtica dioica L.). Post Fitoter. 2010, 4, 199-204.

4. Bisht S., Bhandari S., Bisht N.S.: Urtica dioica (L): an undervalued, economically important plant. Agric Sci Res J. 2012, 2 (5), 250-252.

5. Różański H.: Pokrzywa - Urtica w fitoterapii. http://www.luskiewnik.pl/ urtica/opis.htm (26.11.2013).

6. Činčura F., Ferákowá V., Májovský J., Šomšák L., Záborskýj.: Pospolite rośliny środkowej Europy. Państwowe Wyd. Rolnicze i Leśne, Warszawa 1990.

7. Górnicka J.: Apteka natury. Poradnik zdrowia. AWM, Warszawa 2003.

8. Nowak R.: Natura - niedoceniane źródło kwasu askorbinowego. Post Fitoter. 2004, 1, 14-18.

9. Bonenberg K.: Rośliny użyteczne człowiekowi. Instytut Wyd. Związków Zawodowych, Warszawa 1988.

10. Gumowska I.: Ziółka i my. Wyd. PTTK „Kraj”, Warszawa 1983.

11. Uluata $S$., Özdemir N.: Antioxidant activities and oxidative stabilities of some unconventional oilseeds. J Am Oil Chem Soc. 2012, 89 (4), 551-559.

12. Krauze-Baranowska M.: Pokrzywa leczy. Panacea. 2005, 3 (12), 27-28.

13. Sroka Z., Gamian A., Cisowski W.: Niskocząsteczkowe związki przeciwutleniające pochodzenia naturalnego. Postępy Hig Med Dośw. 2005, 59, 34-41.

14. Augustyniak A., Skrzydlewska E.: Zdolności antyoksydacyjne w starzejącym się organizmie. Postępy Hig Med Dośw. 2004, 58, 194-201.

15. ChrubasikJ.E., Roufogalis B.D., Wagner H., Chrubasik S.A.: A comprehensive on nettle effect and efficacy profiles. Part I: Herba Urticae. Phytomedicine. 2007, 14 (6), 423-435.

16. Gałecka E., Jacewicz R., Mrowicka M., Florkowski A., Gałecki P.: Enzymy antyoksydacyjne - budowa, właściwości, funkcje. Pol Merkur Lekarski. 2008, 25 (147), 266-268.

17. Skólmowska M., Kmieć M.: Enzymosomy antyoksydacyjne - właściwości i zastosowanie. Postępy Hig Med Dośw. 2011, 65, 640-644.

18. Bradford M.M.: A rapid and sensitive method for the quantitation of microgram quantities of protein utilizing the principle of protein-dye binding. Anal Biochem. 1976, 72, 248-254.

19. Aebi H., Suter H., Feinstein R.N.: Activity and stability of catalase in blood and tissues of normal and acatalasemic mice. Biochem Genet. 1968, 2 (3), 245-251.

20. Vives-Bauza C., Starkov A., Garcia-Arumi E.: Measurements of the antioxidant enzyme activities of superoxide dismutase, catalase, and glutathione peroxidase. Methods Cell Biol. 2007, 80 (19), 389-391.

21. Wadhwani T., Desai K., Patel D., Lawani D., Bahaley P., Joshi P. et al.: Effect of various solvents on bacterial growth in context of determining MIC of various antimicrobials. Int J Microbiol. 2008, 7 (1), 1-6. 